\title{
静 電気についで
}

\section{はしがき}

慗祆工業に执いて，特にハイスピード抄組機のカレ

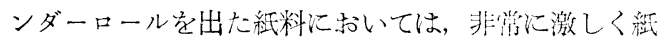

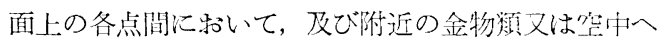
放電しているのが見られる。又上質紙関係ではコンデ ンサーペーパー抄造汇際し，スーパーカレンダーの出 口において附近の磨を吸引儿品質上思わしから双結果 を及ぼす等静電気と深い関係がある。

この誌面ではこれ等静電父がどうして発生するか, 又その除去にはどんな方法があるかについてできるだ け常識的に述べて見た。ただし, 電磁学上の用語につ いて正しい理解をもって戴くことは一般的には無理か と思われるし，それについて詳しい貺明をしている訳 にも行かないので，極力そのような用語の使用はさけ た稓りであるが, 止むを得ず一, 二使苚した点, 御諒 承を願うものである。

\section{1. 静電気の存在}

人間が初めて電父を発見したのは静電気であった。 $\mathrm{BC}$ 約 600 年頃のギリシャの哲学者タレス（その頃の 哲学者は即数学者であり即物理学者であったらしい) が琥珀を毛織物で摩擦すると整い物体を吸引浔るよ5 になることを発見したという伝説がある。

そして今日使われている Electricity（エレクトリシ ティ）電父という語はギリシャ語で琥珀を意味する語 Electron（エレクトロン）からはじまったものだそう である。こうして見ると静電父の存在は，随分大装か ら判っていたものらしい。

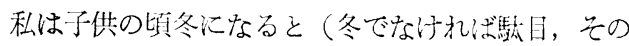
理由は後述）紆の小片を火鍊であぶり大忙ぎでイガク

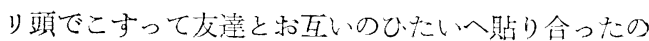
を覚えている。これが電気だと教党てくれる大人は多 かったが，これが天井にともっている電合といかに罢 らのか教觉てくれる人はいなかった。諘中電登位をも ってもよいじゃないか等と考党たことも希ったのがい まから思うとなつかしい。

その他大きくは自然現缘として雷や，有名なセント エルモの火から猫の背比至るまで, 私達は日常静電余

原稿受付 32.8 .8

** 本州製紙 $\mathrm{KK} \cdot$ 施設的
並木 漖**

の存在を絶光ず見か沙るが，何分にも静電父は定常的 な電磁作用を殆えど起さないのでエネルギー源として 利用することができない現状でせる。

然し最近，いささかこれが利用抾も考克られてい るので後で少しく触えることとする。

\section{2. 静電気はどうして起るか}

ずっと幄く生れた動電気がその理满が解明され, 利 用が十分発達しているのに比し，兄贵分の静電気の灰 は発有不良で末だ発生の理論が碓立していない。勿論, 古来幾つかの説は樹てられて来たが，その後に新しく 出て来る新現象兴説明することができないため止むを 得ず降服しリリーフに引継いでいる状態である。

近来, 物質の構造が明がされて来たので次第に静 電父発生の理論子確実になり，系統化さ机て来たらし い。然しこれを詳細化説明することは，難解であり， 又この誌上で記すのは目的からいっても不意でないの で，以下丞めて常識的に現在こ5であろ5 と考党られ ていることを挙げて見よう。

\section{2-1 異種物体の接触}

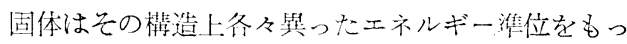
ているため，罢る物缷を接触させると電位差が生じ， 雱子の移動が生じる。その結坚電于の偏在が起って带 電現象となるという説明が岕る。

この説は金属間化刘しては上くあてはまるらしいが， 湫電体及び流体に詨しては敏密にいらと異論があるら しい。然し一般にこ礼学拉張して説明をつ活て，考兄 ているようである。従って買種の物体が接触すればす ぐ频電与る。守して帯電する状態はエネルギー準位の 離れているもの同志の接触漂ど大きくなる。又接触す る物体によって带電の種類, 即ちいずれが正(+), 負(-),

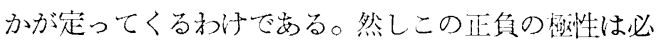
げしもこの暊の通り汇は行かない場合も多くあるらし いのでまる。

\section{2-2 同種物体の接触}

所が同種の物質でも接触するとッはり蒜電すること が判っている。

これ詨しては，危所的にエネルギー構造が異るか， もら一つは摩擦化よるものだといら説がある。摩擦に よる場合は，同種の物質の间志でも表面のミク口的状 怹は各々皆同じではないから, 熱の発生状態に差が生 
じ従って熱電位差による带電現象が起ると考えられて いる。この場合はいずれ側が正極か，真栖か定らない わ恬であ。

同時に又この摩擦熱は局部的には非常に高くなるの て（一説には最高 $1000^{\circ} \mathrm{C}$ といわれている）物質が 分解花しくは酸瑱してイオンを生じ带電与る現象子起 ると考光られている。

\section{2-3 静電気発生のまとめ}

この摩擦による静電気発生の现像は私達が简に一青 よく経験するものであるが，摩擦と接触とは何时でも 同時に行われるものであるから上記さつの原因によっ て大部分の静雷気は発生するるのと考えてよいである 5。摩擦によって国体のミクロ的な凸四の小部分が破 崚され，部分的飞発生する温度は想像外飞高いと発表 されている。

然しながらこれ等の現象はいずれも定性的には説か れているが，極く特殊の実験によるもの以外は定量的 には説明されていない。この点は今後測定法の進歩と

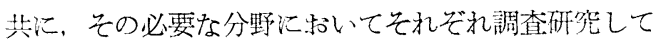
行くべきであろう。

\section{3. 静電気が外部へ影響を及ぼす場合}

接触した 2 つ物体間に静電気が実際発生している 場合でも，両者が接触した状態にある間はその界面て 電荷（電子或いはイオン化した物質の微䊀子）の移動 が行わ机るだけで外部に対しては殆んど影響を及流さ ない。

所がこれらの物体が離れはじめると、いままで接触 していた両面に互いに黑った電何をもったまま間隔が 広くなるので两者間の静電容量が小さくなるにつれて 雨者の電位差は上帠し，ここにはじめて带電の影稳が 外部に䫏われはじめる。

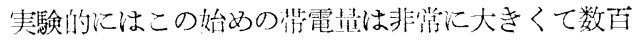
$\mathrm{esu} / \mathrm{cm}^{2}$ (静電単位で 1esu は篹用简位の $3 \times 10^{-9}$ 倍) の带電を子得られたといわれているが，一般にはこの 1/100の数 $\mathrm{esu} / \mathrm{cm}^{2}$ 位であるらしい。

然し筀気の絶䋎の破填されるのは， $3 \times 10^{4} \mathrm{~V} / \mathrm{cm}$ 位 の電位傾度であるから空気コンデンサーとして $8 \mathrm{esu} /$ $\mathrm{cm}^{2}$ 位の電荷以よって生ずる電場注当する。

これは2つの平行板の間で考党た場合であるから， 表面に山上がある2者間の場合には部分的には針端放 電とも考えられるので，この破堎に相当する電位傾度 の值は更に下趈るから带電した雨者間では容易に空父 の絶䋑が破れ放電が開始されるに至る。

\section{$3-1$ 放電の影響}

放電が火災の原因となるのは当然であるが，ここで
はとのことは後述するから触れないで带電の状沉のみ についてのみ考えることとする。

放電を開始するということは急激汇正，負の電荷を 中和するということであるから，この放電現象で電荷 は減少してその時の状況から定る特定の值なでになっ て了うこととなる。斯ち残った電荷は発生したものよ り常に相当少いものになる。

\section{$3-2$ 洩漏抵抗の影響}

次心踔電物自身に洩漏抵抗が女る場合には，この抵 抗を通じて放電し電荷は更汇減少する。

以上の放雷と洩漏の現象によって物体の带電量が左 存されることは重要なことである。

紙のよ5な誘需体に招いて関倸混度 $80 \%$ \%上の場 合には帯電しないといわれているのはこのような状 態比紀かれた紙は大体 10 \% 位の水分を昘有与るよ5 になり，医の中の水分が 10 \%以上ある時は，電荷が 速かに洩漏し消失することを意味する。随ってカレン ダーロールを出たばかりの過乾で父温より高い温度に める紙料については，電荷の洩漏は考えられない。放 電による電荷の減少があるばかりと思われる。又静電 父の災害の大部分は上記の放電によるものであるが， この放電に 2 種あることを記して和く。

一般に電荷が均一に分们して㧍り連続的な带電物の 流れ汇徉って放電するような場合には，大体コロナ放 電であって火災の恐れは特殊の場合以外ない。ただ吸 引力，又は反撥力によるトラブルのみである。

然しこれらの電荷が部分的に集中し或いは蓄䅡され て放電すると火花放電を起すので危険度が急增する。

この現象はウィムズハースト起電器で放電実験する 場合，ライデンびんを接続しない埸合と接続した場合 の放電状態の差を思い起していたたけけばお判りのこと と思う。

\section{4. 製紙工業と静電気}

\section{4-1 製紙工業における静電気の発生}

以上一般的に静電父がどうして発生なるか, 又発生 した後どのようにして外部に影響を現わすようになる かについて概急的に遮べて来た。こ机を製紙工業に当 てはめて見ると抄紙機に抋いては，紙料は常に種々の 種類のロール, 毛布, 綿有, 又は合成緎維と接触し且 つ摩擦され，しかも高温状態に际かれているのである から発生の機会は凡る所化あるわけである。

然し洩漏抵抗值の低いクーチ, プレスの部分では, たと八発生したとしても外部に対して発現しないので, まずドライヤーの朔半部以前には带電状態は見られな い。最も顕著汇発現するのはなんといってもカレンダ 
一を出た所からリールに入るまでの間である。紙料の 乾燥程度, ロールと紙料の温度差, 紙料表面の摩擦等 静電発電機と申しても差支觉ない恵まれたコンディシ ョンである。

スーパーカレンダーに执ける場合も同様で㐫る。

\section{4-2 製紙工業における静電気の悪影響}

カレンダーロールを出た紙料上の電荷は急激沉ポテ ンシャルか高くなるため空気の絶縁を破り盛んに火花 放電する。この状態は星間でもよく視察し得る程であ る。然乙縕料の各小部分每に即䓃電気溶量の小さい部 分每に放電して?い1 回の放電是が少いので火災を生 ずる程度には至らないのが情通である。

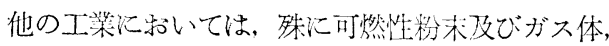

又は引火性の油脂，火薬等を报う工業に䗆いてはこの 放電現象に伴万伦険性は到成慗紙工業の比でなく事夹 幾多の惨事をひき抏こしている。又写真フイルム製造 工業沈劣いては，火災に至らない程度の小放電で无現 像するとリヒテンベルヒ像を生ずるとい5厄介な現象 があるので界質上さぞかし缷骨折りのことと察する次 第である。

製紙工業に招いては，特に発生した電荷を大蒀集め て一度に放電するような施設がなされない限り火災の 心配はないのであるが，放電だけで中和しきれず残 った電荷は静電誘導により附近の損紙, 小片, 䴟等の 表面に異種の電荷を誘発して，これを吸引するといら トラブルを生ずる。これ等はただちにリールで巻取り の中へ巻込孪れてしま5か, カッターで切られて次々 と程重祊られて了5ので, 再びこれ等の付着した障害 物を除去することは殆えど不可能である。

又紙の乾燥が過度であったり, 空気中の湿度が少か ったりする場合には，紙は非常汇上い緦縁物となるの で，これの残留電荷は相当長期間絟の表面に残ってい る。そしてその後の行程である数点及, 選別の時, 拉 互い汇密着したり, 又は縁が反撥してまくれ上ったり してトラブルを生ずる。

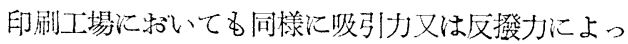
て印刷のずれ, 紙の密着, 反撥等の面倒を引き扢こす。

\section{$4-3$ 静電気の利用}

先汇他産業に和忛る静電気の障害は製組工業に招计 るものの比でなく非常に危険なるのであることを述べ たが，静電父の利用方法も全然ないわけではないので 次化 $1 ， 2$ 著明なものを举げて掠こう。

製紙工業化一番関係が深く古くから知られているも のではコットレル集䴤器がある。この装置はいまさら 説明なるまでもなく KP プラントの回収ボイラーに括 いて廃ガス中からソーダを回收する場合, 又微粉炭
燃焼ボイラーの廃ガスからフライアッシュを捕集する 場合等汇使用されている。

この装㯰の原理は極性の異る電荷は吸引し合う静電 気の力を利用したもので，微粉を含んだガスを細線の 陰極, 板状の陽極よりなる直流高王電場の中へ導入乙 陰剚からコロナ放電を起してガス中の微粉を带電せし めて陽極汇吸引，堆積せしめるもので岁る。

その他, 最近発達したものでは静電塗装法, 静電分 離法等がある。これ等はいずれる微䊀粉状態のものに 荘電せしめ, 直流高压の電場中て作用せしわる法で める。近時半導体理論が進步し半導体を利用した整流 器が多く, 容易汇製作されるようになったのでこの種

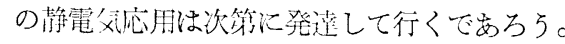

\section{5. 製紙工業における静電気障害対策}

\section{5-1＼cjkstart静電気の発生を少くする方法}

製絟工業汇打汗る静電父溌生の温床注先に述べた通 りドライヤーの後半以後に执いて，特汇カレンダーを 通過中高洫のロールで加圧され，且つ強圧の下でスリ ップさせて表面の平滑化が行われる間と考学られるか

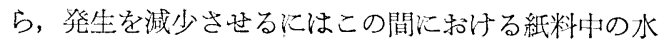
分を必要以上に少くしないこと，即ち過乾燥化しい ことが唯一の条件である。然しながらこの方法として も品質の向上の点から見ると往々好しくない場合があ るし，一方抄速は上算する一途であるから静電父発生 量を诚少せしぬる效果的な方法はいまの所見当らない。

\section{5-2 発生した電荷を除去する方法}

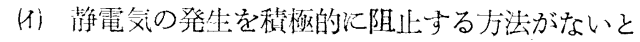
すれば，発生した電荷を除去する方法を考觉る他ない。

先汇述べた如く州電した紲料がロールから離礼ると 急速に電位が界り空気の絶縁が破れて放電するから， 自然的汇電荷の量は相当中和されて了弓のであるが, な怙電荷が残留している。これ等は前より低い電压の 状態で分有しているから紙沈なるべく近い距離に放電 すべき導体を設四して括计げ, 絓料表面の電荷はこれ 㳊電して更汇減少与る。この際注意与べきことは, この導体と紙との静電容量をできるだ计小さくするよ らにしなければ効果が少いといらことである。即ち具 体的には細い針金の上うな導体觉組汇接しておくこと が有利である。

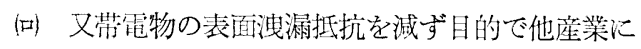
おいてはロール表面又は㧼品にイオン性の表面活性郕 老塗付与る方法も行われている。然し整維工業汇扔い ては原洒上杽面及び電荷残留の障害程度が他産業化較 べて重大でないので未だ行われてはいないようである。

(以)（们の場合の如く䋊料汇接して放電電極を設置す 
れば電荷は相当程度放電により減少するが，なお残留 電荷を認める。これを殆えど完全に中和して了う為沉 最も一般に行われているのは電気的汇電荷を除去する 方法である。

次沙しく詳細に原理及び構遗を記すこととする。 原理はいわゆるコロナ放電を紙料晌向って行うもので ある。この装置汇は原理上直流型のも交流型のる のと沙洘兄られる。

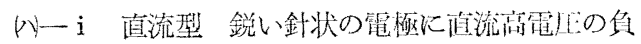

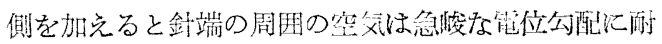
亲きれず絶䋑が破れてコロナ放電の开象を生ずる。即 ち高電压で針端から放出された一部の管子が空気分子 飞衙突し，空父分子をイオン化して針端の附近を導体

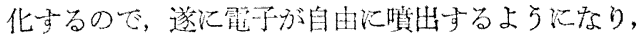
㕵攽分子は更にイオン化老強化さ礼て行く。かくして

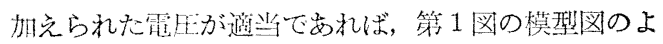
5 亿電子は产易汇組料上飞到達し絓料の電荷が正の場 合には山和して䇝荷は消失导るに至る。

\section{第 1 図}

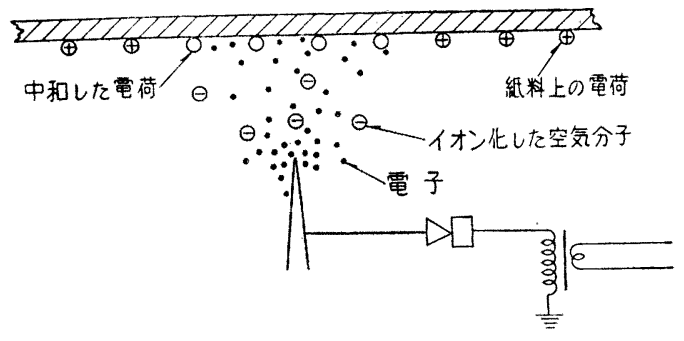

同時に負以イオン化した筀父分子も電場の駆動によ り同様の作用をするが，これ等は質量が非常に大きい 数電子より㜊れると考兄られる。除去すべき電荷が負

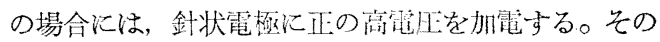
時附近の遊漂している負イオンは急速汇針端沉吸引さ れ，その際他の空父分子と衝突与るので，加速する電 压が十分高ければ針端附近はイオン化されやはりコロ ナ放電を生ずるから，これらのイオン化した正イオン 分子で真の雪㣮を中和することができる。

このよう汇流のコロナ放電で静電気を中和する場

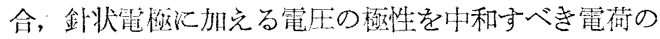
極性と反対にしなければ効果のないことは勿論である が，更汇との大きの調整を適当汇しなければかえっ て中和後近涪電させて了うことになる。又带電の極 性が正負一定していれば問題ないが一般には極性が一 定せず，スペース的にす時間的にもランダムに㴖電し ている場合が多いので，この直流方式は效果的でめる にはちがいないが一般的でなく，且つ絶党ざる雱圧調 整を必要とする等の点から殆えど使用さ机ておらない。
け人一 - ii 交流型この型も直流型と同様な構造であ るが，加える電压が交流高電压となっている。比較的 安価汇できるので広く书場にも売り出されて和り又使 用されている型である。

前と同㥞の針状電極洨交流高電压を加えた場合, 負 侧の半週期当っていた時は直流型で電極を負に加圧 した㤼合と同じ原理でコロナ放電を执こし電極を中和 与る。次の半遇期には針状電極は正に加電されるが，

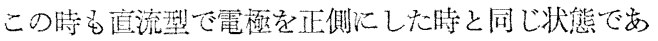
るが，前半週期においてつくられた真イオンの一部が 強いニネルギーで電極に吸い尽され周用の架父はイオ ン化される。この場合は電虂が正であるので正イオン が多量比生ずることとなる。即ち正負いず机の䁚期で

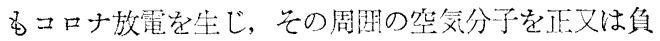
Кイオン化吉る。呑してこ侊らのイオンが絓料の静電 気汇選択的炕結びついて中和作用を行らことになる。

直流型では同種のイオンの方が多いので效果的であ ったが，交流型ではイオンが電芬で加速されている間 飞正イオンと負イオンとが衙突により中和して了うこ とが考光ら礼るので效䜌は下ること汇なる。

又コロナ放霍を持絸する範围で，イオンの発生を十 分多くするように電生を上げて和けばよい方，余り上 げすぎると火花放電となって危険である。

以上の理由から，中和すべき带電面から余り離して 除電する電極（普通除電バーといっている）を設置す ることは，效率も下るし電圧も高くしなけ机な゙ならな いので得策でない。実際の機峨は種々の陪品名で売ら れて蛙り，各々特長を有している上うであるが，いず れも交流型である代表的な構造を第2 2 四仁示す。

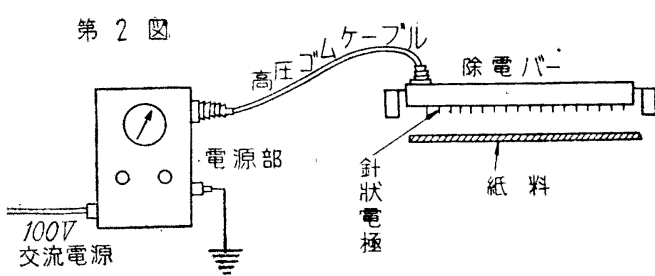

設借は電源部，漹線部，電極部から成っている。電 源部は普通バイブレーターにより変压器の一次電流を 断綿してコロナ放電を発生し易いよう汇高周波尖頭型 の高電压起小型設供で発生しているようである。電圧 も種々あるが $5,000 \mathrm{~V} \sim 8,000 \mathrm{~V}$ 程度である。

けy-iii 注意事項 ここで注意すべきことは，この 種の機栈ではこ礼を取报う者は電気専門の技術者を対 照とせ殴ことである。

即ち尊線及び電極は勿論使用電圧汇長年酎学るよう できているべきであるが，若し鄂って露出部へ触れて 
も人体に危険がなく，又電極部で短絡しても弧光放需 を生じて火災の危険を生ずる等の拈それのないように 設計されていなくてはならない。そのためには電源部 にコロナ電流を危険值以下に押光得る高抵抗を有する こと及び電極部には導線部の容量充電電流の瞬間放雷 を防ぐためやはり適当な高抵抗を挿入することが必要 であろう。又高周波電流であることを利用して䬿栖内 のフィーダーと針状電極との結合を容量的に行ってい るものも岕るとのことである。(第 8 図)

\section{第3图}

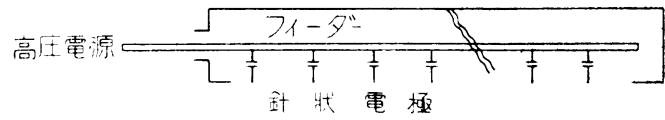

結合谷量は極めて小さいものであるから哭って針状 電極を接地したり，人体がこれに触れたりしても危険 はない。いずれにしても除電効果が十分得られるの文 ならず，危険防止の点にも十分点を版た製品学選択 すべきである。

曰 放射性同位元素（アイソトープ）を使用与るも の 除電効果, 取扱いの難易については未経験なので なんとも言い兼权るが，最近脚光を浴びて出現して来 た放射性同位元素を使用したものもあることを一音御 紹介しておこう。

これには $\alpha$ 線型と $\beta$ 線型とある。 $\alpha$ 線型は主とし てポロニウムを使用しており，r線は出さないので安 全率は高いが反面高価である。半減期は䄪20年であ る。 $\beta$ 線型は主にタリウム 204 が使用されている。半 隇期は約3年である。

原埋は放射された $\alpha$ 線又は $\beta$ 線が空気分子に衝突 しこれをイオン化する現象を利掤したものである。従 つて質量の大きい $\alpha$ 線の方が効果は㺈く $\beta$ 線の方が 弱いと考兄られる。又コロナ放琶を利用したものと珙 り，生成されるイオン数は $\alpha$ 總及 $\beta$ 線の通過距離で 定って?るので莹電物との間隔を相手打の電荷の強さ で適当汇選ばなければならない。即ち余り近つけて使 用するとイオン生成を十分ならしめない恐れが女るの でか方って作用が弱くなるから距離の決定には相业 考慮しなければならない。

以上で現在行われている静電父除去についての概略 の説明を終るが，次に簡単に静電気の测定方法につい て記しおく。

\section{6. 静電気の測定}

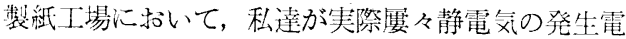
た及び発生䀧を測定することは余り必要がないように
見えるし，又測定するにしても特殊の専門測定器具を 購入しなければならないので，静電気の测定法につい ては余り知られていない。

静電谷の测定には：

1. 表面電荷密度及び表面電位の測定

こ礼は製絓工場に和污る場合の如く絶緣物の表面に

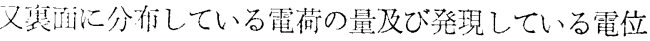
を测定与る方法で岁る。この他に

2. 体秘電谓密活の测定

‥ 空間電倾密湜の测定

などあるが，俈紅工、棠には殆んど関倸がないので略す。

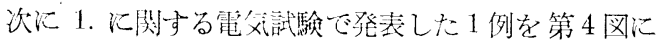
宗劣。

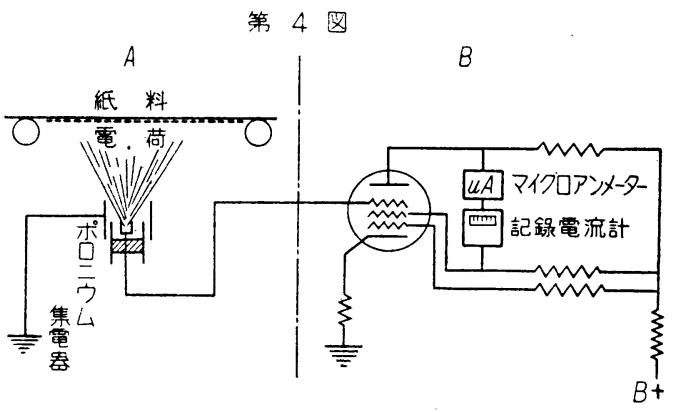

第 4 図中 A 部はポロニウム集電器で， $\alpha$ 線を放出 して空父分子をイオン化し，带電物との間獢をかけ て测定する電荷を呼び奇せるものである。B 部は真筀 管電压計で炛った微量の静電気の生ずる電压を測定す るものである。

この测定方法の細は每門的になるので省略するが， なお諳しく怙和りになりたい力は電気試験所木脇久智 氏が盖しく研栄墖文を発表せられているので一読せら れたい。

\section{結言}

以上まとまりのつかないまま静笔父についての外貌 を述べて来たが，省りみるに製紙工莱に打いてはその 障害が余りひどくないため，これに対する調査侀究が 等閑に付されていたきらいがある。除去装置を設偖すす る場合にしても唯よい加減のものを設供してまに命わ せているといった程度であった。乞して效果めったと か，大して效果がなかったとかいっても，どの装䈯が よいのか判定の根拋がすこら゙るあやしいものである。

今後はもっと電荷の量, 電位差等について夷験的研 究を進めてそれ汇立朋して效果ある処置がなされなけ ればならないと思うものである。 